\title{
Service Analysis at Investment and One-Stop Integrated Service and Labor Office (DPMPTSP Labor) Pekalongan Regency
}

\author{
Susi Sulandari ${ }^{1}$, Herbasuki Nurcahyanto ${ }^{2}$, Aufarul Marom ${ }^{3}$, Dyah Hariani ${ }^{4}$ \\ $\left\{\right.$ sulandari_susi@yahoo.co.id ${ }^{1}$ \} \\ Universitas Diponegoro, Indonesia ${ }^{1,2,3,4}$
}

\begin{abstract}
Pekalongan local government through the Investment and One-Stop Integrated Service and Labor Office (DPMPTSP Labor) is currently actively implementing innovation. One of the innovations is the Integrated Licensing Information System of Pekalongan Regency which is abbreviated as SIP TENAN and Steady Entrepreneur Solutions (Shinta Sah Bu). This research goal is to define the service and examine the service quality in the DPMPTSP Labor Pekalongan Regency. It used the descriptive qualitative method. Moreover, the result showed that there are two models of DPMPTSP Labor Pekalongan Regency services those are manual and OSS (SIP TENAN, and SINTA $S A H B U$ ). The results revealed several service indicators in the DPMPTSP Labor Pekalongan Regency aren't maximal, those are the timeliness of services, and also there are shortages, especially in the Human Resources (HR) sector. The influencing factors found are the limitations of the person serving, the limited time, the social level of the society, the economic level, as well as the different levels of education. The advice can be given are, it needs Helpdesk personnel addition, more enhanced socialization of OSS, the addition of human resources, as well as to develop cooperation especially for the image design of the business locations' sector.
\end{abstract}

Keywords: Innovation, Licensing, Human Resources, Budget, Incentives

\section{Introduction}

The bureaucratic reform grand design of 2010-2025 is a reference for all the ministries, institutions, and also local governments to create good governance. Bureaucratic reform nowadays becomes the government's duty both central and local government. It is so important considering the public services performance that hasn't been optimal. Indonesia's public services performance can be seen from the Ease of Doing Business (EoDB) that showed a result score 67,96. Indonesia is ranked 73rd out of 190 countries based on EoDB [1]. Furthermore, based on Burden of Government Regulation indicator in Global Competitiveness Index, Indonesia got 29th ranked with 50, 8 point out of 141 countries. It getting decrease than 2018 when Indonesia got 1, 2 point bigger in 26th ranked out of 140 countries. The lack of bureaucratic performance awareness as well as the presence of PP No 81 in 2010 has been caused several ministries, institutions, and also local governments compete to actualize good governance [2]. The opportunity to actualize it is getting bigger when the regulation 'PP No 24 of 2018 ' concerning electronically integrated business licensing services is declared. There are several local governments that start developing online services in terms of encouraging the 
embodiment of bureaucratic reform embodied in PP No 81 the year 2010 [3]. One of those local governments is Pekalongan local government.

One of the Regional Device Organizations (OPD) in Pekalongan regency that starts bureaucratic reform is the One Door Integrated Investment and Service Labor Office (DPMPTSP Labor). DPMPTSP Labor was formed based on Regional Regulation (Perda) of Pekalongan Regency Number 4 of 2016 concerning ordering and arrangement of district apparatus. DPMPTSP Labor of Pekalongan regency is trying to implement several innovations as a form of bureaucratic reform, it caused by they are being realized that their performance was not optimal and it will bring up several problems and decrease the quality of the services of DPMPTSP and Labor. DPMPTSP Labor is a department that has responsibility of managing various matters of licensing as well as addressing labor obstacles in the Pekalongan regency. DPMPTSP Labor Pekalongan regency is trying to implement innovation on its services because they want to provide an optimal public service. On the other hand, Pekalongan Local Government claims that manual services nowadays have several shortages such as time limitation, limited human resources and the lack of licensing flexibility. It caused the society has difficulty receiving services from DPMPTSP Labor in variety of the matter, especially licensing.

Pekalongan local government who recognizing the shortages of manual process through the DPMPTSP Labor of Pekalongan regency starts to develop two innovations that became their advantage, namely The Integrated Licensing Information System of the Pekalongan Regency (SIP TENAN) and The Steady Solution of Busy Entrepreneurs (SINTA SAH BU). SIP TENAN is an innovation in the licensing sector to be accomplished online through www.siptenan.id. People can apply for a variety of licenses through this website, ranging from Individual Building License to Special Work Exchange Licenses. SINTA SAH BU is based on the Head of DPMPTSP Labor No 510 the year 2019. SINTA SAH BU is an innovation accomplished by DPMPTSP Labor to require services for people who have obstacles in limited time or busy. Services required in SINTA SAH BU are: (1) licenses service in the night; (2) licensing service through android (WA) and video call; (3) licensing service via on call. Through the service, the people of the Pekalongan Regency have time and media that are truly flexible in managing licensing in DPMPTSP Labor Pekalongan Regency.

Those innovations are created by the DPMPTSP Labor and Pekalongan local government to required maximum service to citizens. Through this innovation, the citizen that has limited time due to their busyness can get the necessary services. The innovation required by DPMPTSP Labor is part of reaching more people's necessary and various types of services. Nevertheless, the various innovations of public services, have to be balanced with maximum service to the people who need such services.

Furthermore, there are several indicators that used to measure the provision of quality services. According to the Zeithmal [4] there are several dimensions measuring the public services provided consist of: Tangible, Reliability, Responsiveness, Assurance, and also Empathy [4]. Meanwhile, based on the Decree of the Minister of Utilization of State Apparatus No. 63 of 2004 the indicators that used for the public services consist of: Service procedures, Time, Service Charge, Products, Facilities and Infrastructure, and also The Competence of Service Office.

In this research, used several indicators consist of the punctuality, discipline, friendliness, fairness, the suitability of payment amount, the ability of the staff, infrastructure facilities, adequacy of human resources, means of complaints, the value of Public Satisfaction index (IKM) to identify the quality service provided by DPMPTSP Labor Pekalongan Regency through innovation SINTA SAH BU and SIP TENAN. 


\section{Method}

This research used descriptive qualitative method, it is a study of a phenomenon obtained from a subject in the form of another group or perspective [5]. Through the method, researchers trying to require an overview and explanation compared to the quality of service contained in the DPMTSP Labor Pekalongan Regency. The data sources contained in this study are primary and secondary data [7]. Primary data consists of live interviews as well as observations developed by researchers while in the field. Secondary Data is data obtained from documents compared to the quality of service contained in the DPMPTSP Labor Pekalongan regency.

\section{Result and Discussion}

\subsection{Service Analysis on Innovation Implementing at the Investment and One- Stop Integrated Service and Labor Office (DPMPTSP Labor) Pekalongan Regency}

Sinta Sah $\mathrm{Bu}$ as an innovation can be interpreted as renewal creativity/ new creation in public service to improve the quality service that form as a program innovation [7]. The services in the DPMPTSP Labor Pekalongan regency are dominated by online services. There are $75 \%$ of its online service and the remaining $25 \%$ of services that are implementation by manual. The online service has developed it easier for people who want to take care of licensing in the DPMPTSP Labor Pekalongan Regency. In the beginning, the management of licensing in the DPMPTSP Labor Pekalongan Regency is implemented by manual method. Nevertheless, it was ineffective, based on this condition, innovation is needed. The innovation known as SIP TENAN and SINTA SAH BU.

To find out the quality service on DPMPTSP Labor, this research trying to identify based on several things in the public services dimension by Zeithmal [4] and indicators under the Decree Minister of Utilization of State Apparatus No. 63 of 2004:

\subsubsection{Punctuality}

The form of certainty of a service is determined by the assurance of the employees who require the service till the person receiving the service is satisfied and confident that all forms of service affairs carried out will be achieved by the speed, accuracy, ease, smoothness, and quality of service required [9], on the service of DPMPTSP Labor Pekalongan Regency, in terms of the accuracy of time especially compared to the services of SIP TENAN and SINTA SAHBU, entrepreneurs no longer busy to managing licensing in the DPMPTSP office \& Labor to register their business license, they only to fill out an online application through the web that has been required with the choice of business needs. This takes approximately 15 minutes. Nevertheless, for those who do not master this charging technology will feel longer, therefore, the confusion faced. 


\subsubsection{Discipline}

The discipline of officers in DPMPTSP \&Labor Pekalongan Regency is quite good. Therefore, every officer who handles SIP TENAN and SINTA SAHBU routinely checks incoming applications.

\subsubsection{Friendliness}

According to Zeithmal [4] enters into the dimension of courtesy i.e. dimensions compared to friendly attitudes or behaviors, friendly that officers have against the wishes of consumers. SIP TENAN and Sinta Sah Bu services at DPMPTSP\& Labor revealed positive results. Some consumers, in this case, are people who have difficulty in administrative management compared to SIP TENAN and SINTA SAH BU often decide to go to the office of DPMPTSP and Labor to achieve the Administration manner, moreover, the facts in the sector point toward to the officers are happy to serve the complaints of the society especially the entrepreneurs.

\subsubsection{Fairness}

Kodoatie [10] said, Minimum Service Standard (SPM) is the obligation of recipients and service requirements structured as tools of central the government and local government to guarantee the society obtains the type and quality of basic services accordingly, in the framework of the implementation of mandatory affairs. Fairness in public service is something that necessity be applied. The results point toward too far in SIP TENAN and Sinta SAHBU services in Pekalongan Regency have been implemented to the maximum. Officers serve each individual according to their order without discriminating against them.

\subsubsection{The Suitability of the Payment Amount}

According to the nominal payment payable by each registrant or the public who has affairs compared to the services of SIP TENAN and SINTA SAHBU. Payments in selfadministration management as stated on the DPMPTSP Labor websites are free or in other words free of administrative management fees. The facts in the environment revealed that it has been accomplished well. Afterward for other payments can be checked in advance in https://oss.pekalongankota.go.id/oss/index.php/id/ by selecting the menu and selecting the payment simulation became active to all payments developed by the existing regulations.

\subsubsection{The Ability of the Officer}

The ability according to the Great Dictionary of Bahasa Indonesia (KBBI) is the capacity of an individual to carry out various activities in a job, as long as the expertise is interpreted as the ability to do something. Zeithaml [4] explains that the capabilities of service units are part of a reliable dimension whose goal is to create the right promised service.

\subsubsection{Infrastructure Facilities}

Compared to tangible dimensions, Zeithaml [4] explains tangible dimensions are dimensions that include physical facilities, equipment, personnel, and communication. SIP TENAN and SINTA SAH BU DPMPTSP Labor innovations to be quite good, according to the 
many types of permissions contained in SIP TENAN web, therefore, entrepreneurs do not need to be put forward to search the application form of licensing as seen in figure 1 .

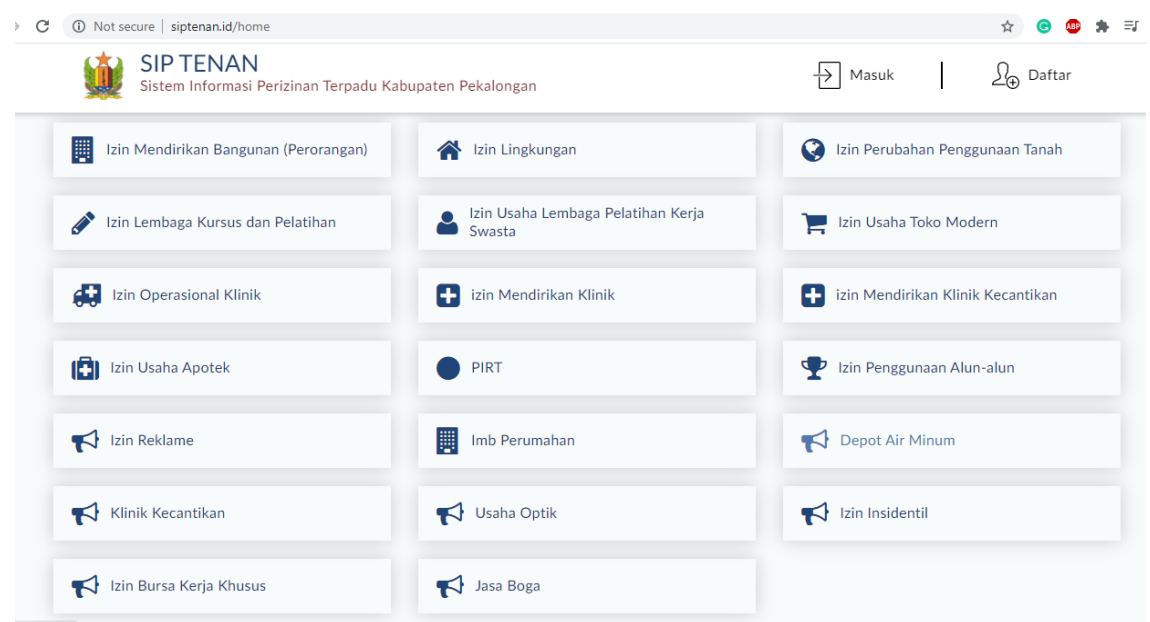

Fig. 1. Website of SIP TENAN DPMPTSP Labor, Pekalongan Regency

\subsubsection{Adequacy of Human Resources}

Comparing to the number of officers handling services behind the innovation of SIP TENAN and SINTA SAHBU services. Throughout the time, the management of data entered into the system is carried out by DPMPTSP Labor officers nevertheless with the increasing application for the issuance of a license, often officers feel overwhelmed. Only in 2019, DPMPTSP Labor handled more than 2,000 license applications.

\subsubsection{The Means of the Complaint}

Required by DPMPTSP Labor compared to the implementation of innovation SIP TENAN and Sinta Sahbu, to be good. DPMPTSP Labor Pekalongan Regency has required advice boxes and contacts that can be contacted in connection with complaints from the society that can be detected easily on the Website of DPMPTSP Labor Pekalongan Regency.

\subsubsection{Value of Public Satisfaction Index (IKM)}

The results revealed that the value of people's satisfaction with DPMPTSP Labor is quite high. According to the index obtained and its predicate, wherein 2018 the index level is quite high which is 81.86 while in 2019 it decreases to 80.99, nevertheless, DPMPTSP Labor Pekalongan regency to be good.

\section{Conclusion}

Finally, we can conclude that The services in DPMPTSP Labor Pekalongan regency are presently dominated by online services, $75 \%$ of its online service, and the remaining $25 \%$ of 
services that are implementing by manual. The online service has accomplished it easier for people who want to take care of licensing in the DPMPTSP Labor Pekalongan Regency. In the beginning, the management of licensing in the DPMPTSP Labor Pekalongan Regency is still implemented by manual method, nevertheless, the way is considered ineffective, therefore innovation is needed, namely SIP TENAN and SINTA SAH BU. Quality of service consisting of timely indicators, discipline, friendliness, fairness, the suitability of payment amount, the ability of officers, infrastructure facilities, adequacy of human resources, means of complaints, the value of Public Satisfaction index (IKM), the results of research there are still service indicators in DPMPTSP Labor Pekalongan Regency that are not maximal namely the timeliness of the service moreover there are still shortcomings especially in the Human Resources sector. According to service users, the factors affecting the service are the constraints of the people served, the limited time, the social level of society, the economic level, and the different levels of education. The suggestion of the research is the addition of Helpdesk personnel, further enhanced OSS socialization, the addition of human resources, as well as in the form of cooperation especially for the image design of the business locations' sector.

\section{References}

[1] European Comission, "Public Services in the European Union \& in the 27 Member States: Statistics, Organisations and Regulations," 2010.

[2] S. Anggara, Ilmu Administrasi Negara: Kajian Konsep, Teori, dan Fakta dalam Upaya Menciptakan Good Governance. Bandung: Pustaka Setia, 2016.

[3] J. K. Kairupan, "Pengaruh Reformasi Birokrasi terhadap Kualitas Pelayanan Publik di Dinas Kependudukan dan Catatan Sipil Kabupaten Minahasa Utara," J. Adm. Publik UNSRAT, vol. 4, 2015

[4] Hardiyansyah, Kualitas Pelayanan Publik Konsep, Dimensi, Indikator dan Implementasinya. Yogyakarta: Gava Media, 2011.

[5] Hardiansyah, Kualitas Pelayanan Publik. Yogyakarta: Gaya Media, 2011.

[6] T. A. Oktariyanda, S. Zauhar, and S. Rochmah, "Pelayanan Izin Mendirikan Bangunan (IMB) Dalam Mencapai Kualitas Pelayanan Publik yang Optimal.," WACANA, J. Sos. dan Hum., vol. 16, 2015.

[7] Sugiyono, Metode Penelitian Kuantitatif, Kualitatif dan $R \& D$ Metode. Bandung: Alfabeta, 2017.

[8] D. N. Fitriana, "Inovasi Pelayanan Publik BUMN ( Studi Deskriptif tentang Inovasi Boarding Pass System dalam Meningkatkan Kualitas Pelayanan Kereta Api PT KAI di Stasiun Gubeng Surabaya ) Diah Nur Fitriana," Kebijak. dan Manaj. Publik, vol. 2, no. 1, pp. 1-10, 2014.

[9] P. A, “The Behaviorial Consequences of Service Quality,” J. Mark., vol. 60, 2001.

[10] D. L. Cahya, "Identifikasi Tingkat Pencapaian Standar Pelayanan Minimal (SPM) Bidang Penataan Ruang Di Provinsi Nusa Tenggara Timur," Planesa, vol. 4, 2013. 